\title{
PERANCANGAN SYSTEM STOK BARANG DI WAREHOUSE BERBASIS WEB
}

\author{
Prasojo Herdy Sutanto \\ Program Studi Teknik Informatika, STMIK NUSAMANDIRI, \\ Jakarta Pusat, (021) 31908575 \\ e-mail: prasojo.phs@bsi.ac.id
}

\begin{abstract}
Abstrak
Pada awalnya PT. MULIA ANDALAN GEMILANG menyimpan stok barang di gudang dengan pencatatan manual atau masih mencatat kedalam kertas dan buku. Pencatatan meliputi data barang masuk dari supplier dan data barang keluar sebagai barang terjual kepada Custommer.

Dengan proses pencatatan data yang tradisional itu perusahaan mengalami banyak kerugian, di antaranya kesalahan dalam perhitungan stok barang secara manual dan pembuatan laporan juga terlambat.

Untuk meningkatkan kinerja operasi perusahaan maka perlu adanya pengembangan dan perbaikan sistem pada stok gudang, yaitu menerapkan teknologi komputer secara keseluruhan dalam pencatatan stock gudang tersebut, maka pembuatan program berbasis web sebagai cara yang lebih efektive dan efisien. Hal ini juga akan dapat menghemat waktu pemrosesan data dan cenderung lebih cepat dalam pembuatan laporan data stok barang masuk dan stok keluar.

Kelebihan sistem juga dapat memudahkan bagi pemilik untuk melihat jumlah stok di gudang dari internet. Perancangan system yang diterapkan dalam penelitian ini digunakan metode pengumpulan data dengan melakukan observasi, wawancara dan studi literatur. Penyusunan aplikasi meliputi tahapan pengembangan yang mencakup analisis kebutuhan, pembuatan diagram alir data dengan Uml Modeling juga bahasa pemrograman berbasis WEB yaitu PHP dan MySqli. Untuk Pengujian sistem digunakan Black Box dan pengujian Alpha.
\end{abstract}

Kata Kunci : inventory, stok, informasi, gudang.

\section{Abstract}

At first PT. MULIA ANDALAN GEMILANG keeps stock of goods in the warehouse by manual recording or still records into paper and books. Recording includes data from incoming goods from suppliers and item data out as items sold to Custommer.

With the traditional data recording process, the company suffered a lot of losses, including errors in manual inventory calculation and making reports too late.

To improve the company's operating performance, it is necessary to develop and improve the system in the warehouse stock, which is to implement overall computer technology in the listing of the stock warehouse, then making web-based programs as a more effective and efficient way. This will also save data processing time and tend to be faster in making reports of incoming and outgoing stock data.

The excess system can also make it easier for owners to see the amount of stock in the warehouse from the internet. The design of the system applied in this study used data collection methods by conducting observations, interviews and literature studies. The preparation of the application includes the stages of development which includes needs analysis, making data flow diagrams with Uml Modeling as well as WEB-based programming languages namely PHP and MySqli. For system testing, Black Box and Alpha testing are used.

Keywords: inventory, stock, information, warehouse. 


\section{PENDAHULUAN}

PT. Mulia Andalan Gemilang merupakan sebuah perusahaan yang bergerak di bidang kabel dan peralatan listrik lainnya, berdiri sejak kurang lebih 8 tahun, Mulia Cable sebagai pabrikan, distributor, agen, dealer, toko, supplier dari peralatan seperti kabel listrik, kabel tray, panel listrik dan peralatan listrik lainnya yang di gunakan untuk keperluan Rumah, Gedung, Warehouse, Pabrik, PLN, Instansi Pemerintah, Instansi Swasta dan lainnya. Artikel hendaknya memuat tulisan yang berisi 1.Pendahuluan, 2. Tinjauan pustaka 3. Metode Penelitian (bisa meliputi analisa, arsitektur, metode yang dipakai untuk menyelesaikan masalah, implementasi), 4. Hasil dan Pembahasan, 5. Kesimpulan dan saran (future works) yang berisi penelitian lanjut di masa mendatang

Didalam proses pendataan stok di gudang PT. Mulia Andalan Gemilang masih banyak kendala perhitungan stok barang di gudang. Perhitungan dan menentukan jenis produk yang telah habis sangat sulit dilakukan, hal ini di sebabkan karena penggunaan system perhitungan yang masih manual dan belum menerapkan teknologi informasi yang tepat.

Dalam proses memonitor dan controling stok gudang PT. Mulia Andalan Gemilang saat ini sangat membutuhkan sebuah teknologi sistem informasi yang moderen yaitu monitoring dan controling persediaan secara terkomputerisasi, sehingga memudahkan manajer ataupun owner (pemilik) untuk mengontrol dan memonitor persedian stok barang yang masih ada.

Jika dikaitkan dengan kebutuhan yang lebih jauh seperti pembuatan BEP perusahaan tentu saja dapat mendukung jika sistem dengan teknologi modern diterapkan.

Pada saat ini sistem informasi persediaan stock barang yang berjalan masih menggunakan sistem manual, hal ini akan menyulitkan ketika manajer keuangan membutuhkan laporan stock gudang ataupun seorang owner ingin melihat jumlah barang tersisa yang Ada di gudang, maka dimulai dari manajer produksi yang memberikan perintah kepada staff gudang untuk memberikan laporan stock gudang dan kemudian selanjutnya manajer produksi akan meneruskan laporan stock gudang tersebut kepada manajer keuangan. Pekerjaan itu di lakukan secara rutin oleh pihak produksi. Karena sistem informasi monitoring yang di gunakan saat ini masih berjalan secara manual dan kurang efektif juga kurang efisien, serta kurangnya keakuratan informasi data yang dilaporkan oleh pihak manajer sehingga mudah terjadi kesalahan dalam pembuatan laporan stock gudang. dan sulitnya manajer dalam mengontrol persediaan barang jika terjadi permintaan penjualan dalam jumlah tertentu.

\section{TINJAUAN PUSTAKA}

\subsection{Sistem Manajemen Pergudangan}

Sistem adalah kumpulan interaksi dari sub sistem, dan manajemen adalah ilmu mengelola sumber daya sedangkan gudang adalah tempat penyimpanan barang sementara. Dapat disimpulkan suatu pengelolaan dari aktifitas yang saling terkait dalam aktifitas penyimpanan barang sementara. Diantara aktifitas tersebut adalah penerimaan dari pemasok, handling barang, pengeluaran barang ke tujuan adalah inti tujuan utama dari aktifitas penyimpanan.

Sistem manajemen gudang ditujukan untuk menangani masalah-masalah kritis dan kompleks, menjaga agar seluruh rantai suplai tetap lancar.

Dalam prosesnya manajemen gudang berkaitan dengan pengambilan, pengepakan, dan penyimpanan stok di dalam gudang.[1] 


\subsection{Tata cara penting dalam Gudang}

Pemeriksaan keluar masuknya barang oleh bagian gudang, pemeriksaan ini untuk menghindari adanya retur pembelian dan juga retur penjualan. Fungsi yang lain, juga untuk menguji kelayakan barang yang akan masuk di gudang.

Administrasi dalam manajemen pergudangan juga melibatkan keluar masuknya barang dan retur barang. Sangat penting jika administrasi ini dilakukan dengan tepat karena jika administrasi tidak teratur maka proses produksi juga akan terpengaruh. Kegiatan yang dilakukan dalam administrasi meliputi penerimaan barang, penyimpanan barang dan pengembalian barang dan juga stock opname setiap bulan untuk data auditing dalam perusahaan tersebut

Barang di gudang adalah aktiva lancar yang berfungsi untuk menambah modal perusahaan. Maka sistem ini di sebut juga Inventori yang dilakukan melalui manajemen pergudangan dan akan menghasilkan laporan setiap bulan dalam neraca perusahaan. [2]

Dalam prosesnya Stock opname juga diperlukan dari kegiatan di gudang pada setiap setiap akhir bulan sebagai bagian dari control barang sehingga dapat mengetahui jika terdapat selisih jumlah barang di gumanagemen gudang ini bisa berfungsi untuk pengambilan keputusan yang lebih terukur berdasarkan data-data yang ada, apabila dirasa merugikan perusahaan maka tetacara managemen pergudangan bisa dirubah dengan menggunakan metode yang lebih afektive dan efisien.[3]

\section{METODOLOGI PENELITIAN}

Tahap awal penelitian ini adalah melakukan identifikasi objek yang secara khusus menganalisa arus informasi yang berjalan dan sedang digunakan.

Pemahaman permasalahan yang terjadi semakin jelas yaitu khususnya problem pengelolaan data stok barang di gudang. Untuk mendapatkan informasi terkait permasalahan ini peneliti menggunakan metode penelitian kualitatif, metode ini digunakan dengan melakukan observasi atau studi lapangan, dengan melihat secara langsung proses keluar dan masuknya barang yang terjadi pada Gudang. Pengembangan sistem yang digunakan menggunakan Metode FAST (Framework for the Application System Thinking), yang terdiri dari fase-fase, Scope Definition, Problem Analysis, Requirements Analysis, Logical Design dan Physical Design.

\section{Scope Definition}

Pada tahapan ini merupakan tahapan awal dalam perancangan sistem dimana pendefinisian ruang lingkup dari sistem informasi stok warehouse ditentukan.

\section{Problem Analysis}

Pada tahapan ini Analisa masalah yang terjadi untuk pendefinisian ruang lingkup dan masalah dalam pengembangan sistem informasi,

\section{Requirement Analysis}

Pada tahapan ini kegiatan melakukan pengumpulan data dan menganalisa apa saja yang menjadi kebutuhan pengguna dan kebutuhan system.

\section{$4 \quad$ Logical Design}

Rancangan model diagram yang di usulkan yaitu metode rancangan yang berorientasi objek dengan menggunakan UML (unified modeling language) dan menggunakan software visual paradigma for UML untuk membuat suatu model diagram.

\section{$5 \quad$ Physical Design}

Tahapan ini merupakan kegiatan menterjemahkan logical design ke dalam bentuk fisik suatu aplikasi, meliputi perancangan user interface dan detail design.[4] 
Metode Pengujian yang digunakan yaitu Blackbox testing, metode uji coba yang memfokuskan pada keperluan fungsional software Uji coba Blackbox ini memungkinkan pengembangan dalam software untuk membuat himpunan kondisi input atau data uji yang akan menguji fungsional dan output suatu program untuk menemukan kesalahan.

dalam beberapa kategori dan fungsi yang hilang, kesalahan dari luar, kesalahan output, kesalahan dalam struktur atau kesalahan akses database external. Kemudian untuk bahasa pemograman yang digunakan adalah bahasa pemograman PHP (ver.7), Paket aplikasi menggunakan software XAMPP yang inlude didalamnya aplikasi webserver apache dan database MYSQLI.

\section{HASIL DAN PEMBAHASAN}

\subsection{Identifikasi Aktor}

Aktor adalah merupakan wujud dari seseorang yang dapat berinteraksi dengan sistem. Aktor dikelompokan menjadi beberapa aktor berdasarkan tipe aktor dan aktivitas aktor.

Idenfikasi aktor dapat dari hasil tahapan pengumpulan data berupa wawancara, observasi dan dokumentasi sehinga dapat diproses menjadi stok barang dan penjualan berdasarkan stok barang yang ada di dalam toko. Dari tahapan pengumpulan data, dapat data mengenai gambaran umum instansi serta visi dan misinya.

Berdasarkan aktor yang telah terindenfikasi pada sistem informasi pengelolaan arsip stok barang menjadi tiga macam tipe aktor :

1 Pelaku Bisnis Utama/Primary Business Actor (PBA) merupakan stakeholder yang mendapatkan keuntungan secara terukur dari sistem.

2 Pelaku Sistem Utama/Primary System Actor (PSA) merupakan stakeholder yang langsung berhubungan dengan sistem untuk memicu berjalannya sistem.

3 Pelaku Server Eksternal/External Server Actor (ESA) merupakan stakeholder yang melayani kebutuhan penggunaan use-case.

4 Pelaku Penerima Eksternal/External Reciving Actor (ERA) merupakan takeholder yang bukan pelaku utama, yang melayani kebutuhan penggunaan sistem.[5]

Berdasarkan pada tahap analisis dapat diketahui bahwa aktor yang terlibat dalam Sistem informasi pengelolaan stok barang dan penjualan ini adalah Konsumen, Admin, Bendahara Perusahaan, Pimpinan Perusahaan. Berikut di bawah ini merupakan penjelasan mengenai identifikasi aktor

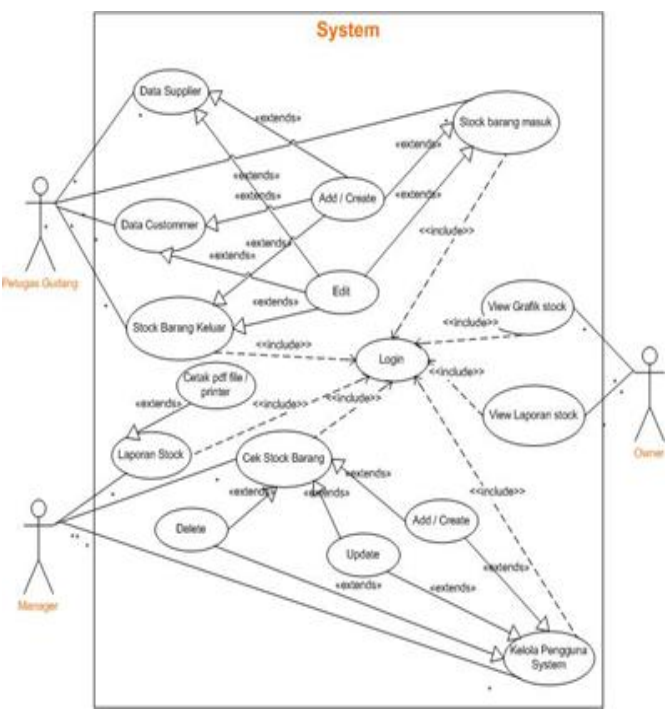

Gambar 1. Use Case Diagram Rancangan model yang di usulkan.

Berdasarkan gambar 1. Use Case yang diusulkan terdapat :

a. Suatu bentuk system yang mengatur pendataan kedalam gudang dan keluar gudang. (Monitoring Stock Gudang ).(Ndlala \& Mbohwa, 2017)

b. Dalam System tersebut terdiri dari 3 (tiga) Actor, yang berperan penting untuk melakukan kegiatan Stock Gudang yang 
diantaranya : Pemilik (Owner), Manajer Produksi dan Staff Gudang.

c. Terdapat 8 (delapan) Use Case utama yaitu : Data Barang, data supplier, data custommer, data Penerimaan, data Pengeluaran, data laporan \& Stock, data user (pengguna).

d. 1 (satu) Include yaitu Login.

12 (dua belas) extend yaitu :Yaitu Menampilkan untuk proses Create / Add, Update, Delete Data User (Pengguna system) dan Create, Edit data Barang masuk, Data Barang keluar, Create, Edit data Customer, Create, Edit data supplier, Cetak pdf file / print.

\subsection{Class Diagram}

Class diagram digunakan untuk menampilkan beberapa kelas yang ada dalam sistem stok gudang. Class diagram mendeskripsikan jenis-jenis objek dalam sistem selain itu juga menunjukkan properti dan operasi sebuah kelas dan batasanbatasan yang terdapat dalam hubunganhubungan objek tersebut. Class diagram memiliki 3 bagian utama yaitu attribute, operation, dan name.

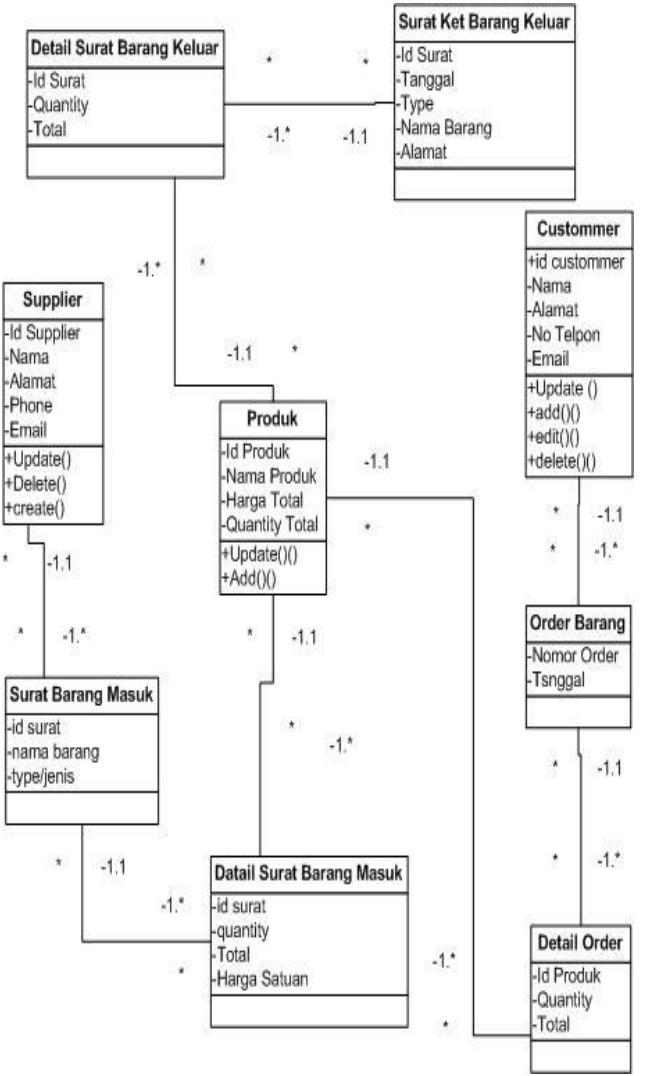

Gambar 2. Class Digram System yang Diusulkan

Berdasarkan gambar 2. class diagram sisitem yang diusulkan terdapat :

a. 9 (delapan) class, himpunan dari objek-objek dengan berbagai atribut serta diantraranya :

tbl_detail_surat_barang_keluar, tbl_surat_ket_barang_keluar, tbl_produk, tbl_surat_barang_masuk, tbl_detail_surat_barang_masuk, tbl_supplier, tbl_custommer, tbl_order_barang, tbl_detail_order.

b. Terdapat 9 (sembilan) multiplicity yaitu hubungan antara objek satu dengan lainya. 


\subsection{Tampilan Sistem stok Gudang yang di Implementasikan}

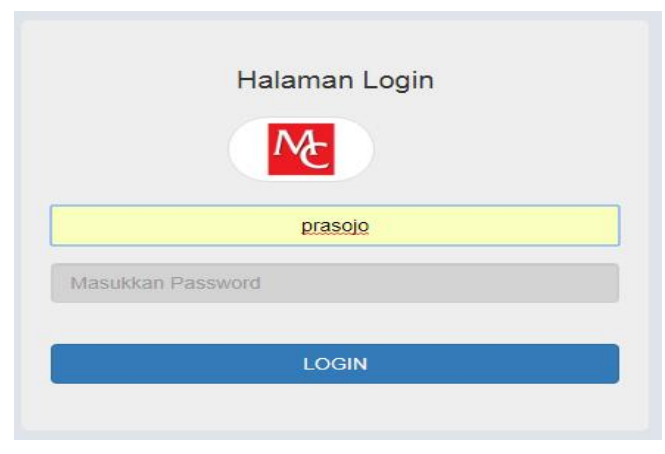

Gambar 3. Tampilan Menu Login User.

Pada gambar 3, Adalah Menu login utama untuk dapat masuk sebagai login user petugas gudang atau Manager sebagai admin yang nantinya akan mengelolah beberapa menu transaksi di dalam system Stok gudang yang masuk dan yang keluar.

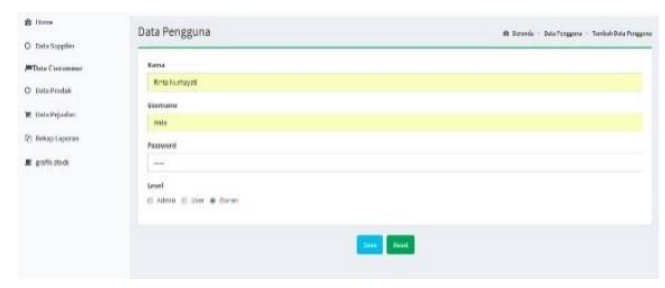

Gambar 4. Tampilan Menu admin menambah User / pengguna.

Pada gambar 4. Tampilan menu admin sedang melakukan penambahan anggota pengguna system, untuk Admin dapat menambah user dan merubah type password sesuai dengan kapasitas aktor yang terlibat dalam sistem.

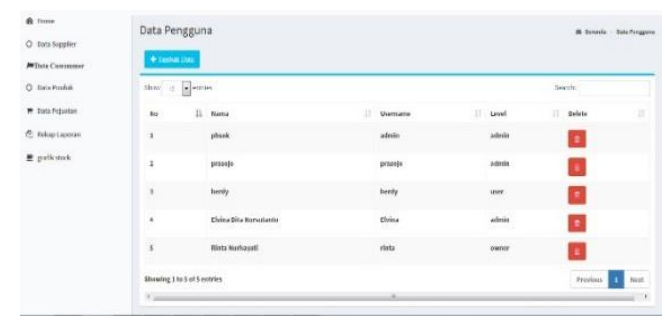

Gambar 5. Tampilan Menu admin telah menambahkan User
Pada Gambar 5. Tampilan terlihat seluruh pengguna yang telah didaftarkan oleh admin sebagai user pegawai gudang, user admin dan user owner.

\subsection{Tampilan penambahan data supplier}

Penambahan data supplier digunakan system untuk menambahkan informasi data pemasok barang masuk ke stok gudang.

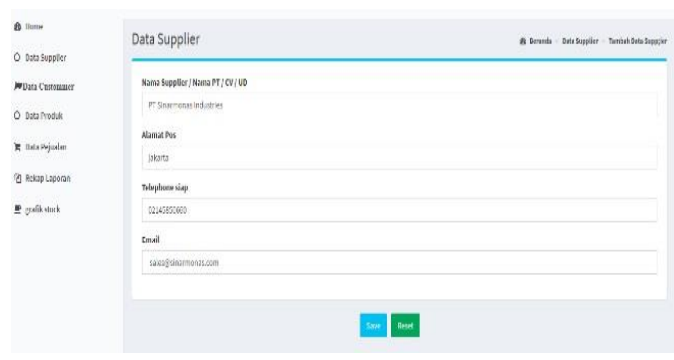

Gambar 6. Tampilan Add Supplier

Pada tampilan menu gambar 6 . Seorang petugas pendataan stok gudang melakukan pengisian data pemasok / supplier yang bersifat hanya satu supplier, data bersifat unix dan tidak ada data yang ditulis sama.

Hasil pendataan ini dapat terlihat pada gambar 7 .

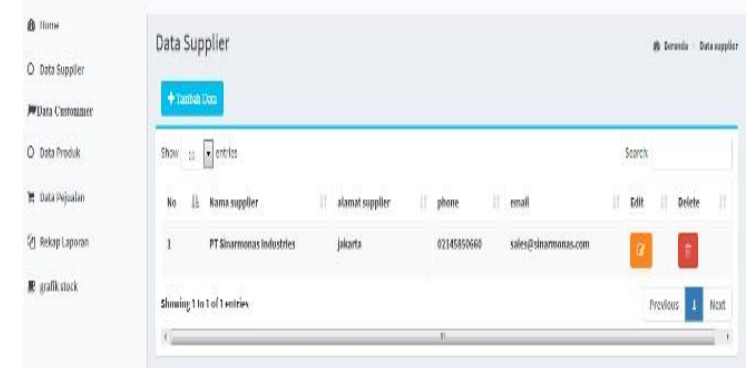

Gambar 7. Hasil Add Supplier.

\subsection{Tampilan add data custommer}

Penambahan data custommer digunakan system untuk menambahkan informasi dari pelanggan sebagai transaksi pembelian barang,

Custommer sebagai pembeli merupakan target penjualan perusahaan ini. 
Hasil pendataan dapat terlihat pada gambar 8 dan 9

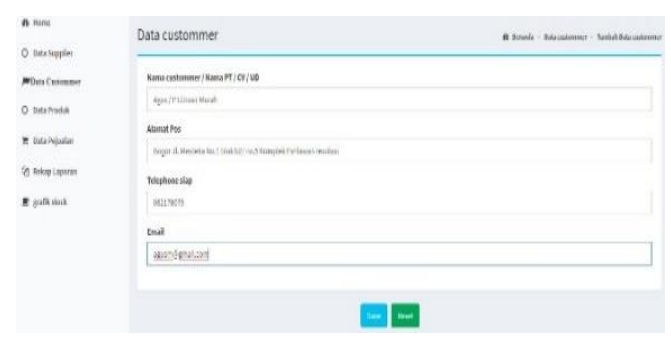

Gambar 8. Add Custommer.

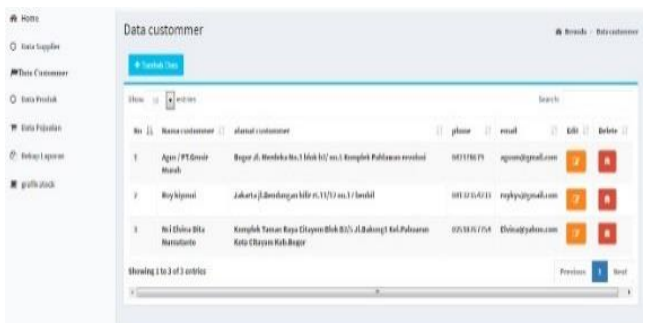

Gambar 9. Hasil Add Custommer

\subsection{Tampilan penambahan data barang}

Sebagai tanda masuknya sejumlah barang yang berasal dari supplier, oleh karenanya penambahan pada form add barang harus di dahului dengan memasukan informasi dari supplier jika Supplier baru bekerja sama dengan perusahaan ini.Data barang dapat di tambahkan

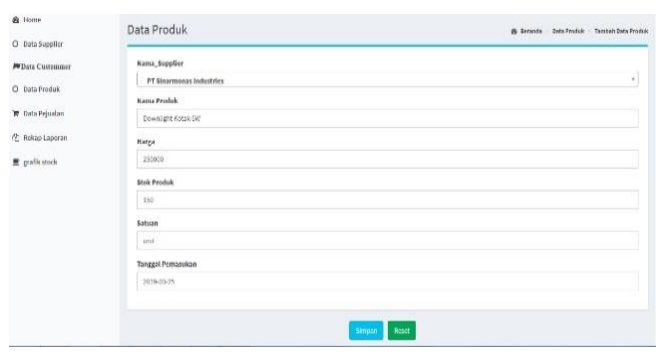

Gambar 10. Penambahan barang masuk gudang

Pada gambar 10 petugas gudang melakukan penambahan barang masuk yang berasal dari data pemasok / supplier.

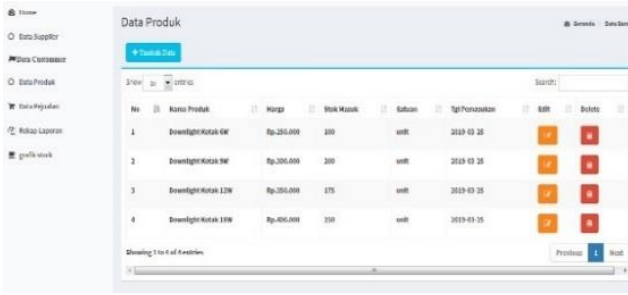

Gambar 11. Hasil beberapa Penambahan barang.

Hasil penambahan barang masuk yang berasal dari kegiatan pendataan petugas gudang dapat di input berulang kali dengan nama supplier yang sama atau produk yang sama sesuai pembelian barang kepada supplier, seperti yang ditunjukan pada gambar 11.

\subsection{Form penjualan}

System transaksi data penjualan yang mengakibatkan berkurangnya stok barang dari gudang, maka dalam system ini kegiatan dilakukan oleh petugas gudang karena telah terjadi pemesanan atau penjualan kepada custommer.

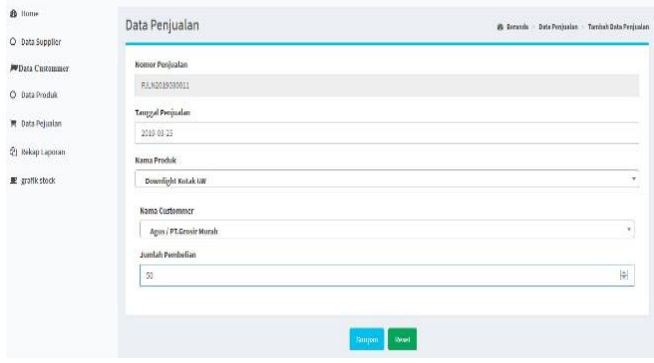

Gambar 12. Penambahan penjualan.

Pada gambar 12 pengisian data dilakukan untuk menambahkan jumlah penjualan. Pejualan dilakukan sampai batas stok suatu barang habis / tidak tersisa dari data yang ada pada system. Hasil transaksi penjualan ini secara langsung mengurangi stok barang yang ada pada gudang, seperti yang ditunjukan pada gambar 13 . 


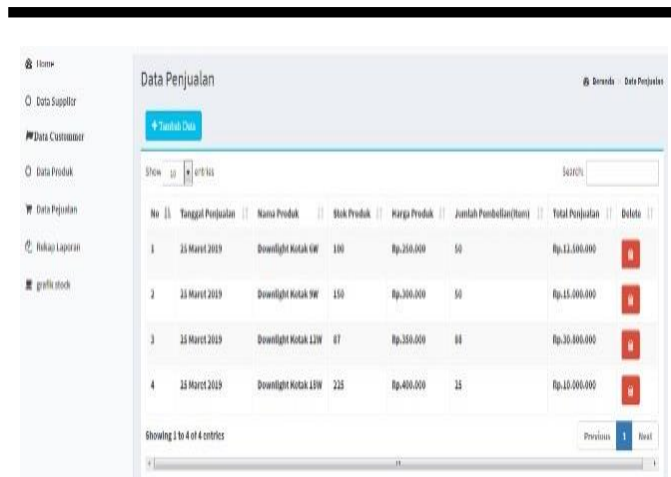

Gambar 13. Laporan Transaksi Penjualan.

Laporan Transaksi penjualan dapat diakses oleh Pemilik ( owner), laporan ini dapat di cetak dalam pdf file atau printer.

\subsection{Tampilan laporan stok minimal.}

Laporan stock minimal adalah bentukan form system yang dapat dilihat untuk mempermudah pemantauan jumlah stok yang tersisa, laporan ini memiliki perhitungan batas minimal jumlah barang yang masih tersisa di gudang akibat transaksi penjualan barang. Jumlah minimal barang yang tersaring dalam laporan ini dapat di setting tetapi oleh pengembang aplikasi atau penulis sendiri.

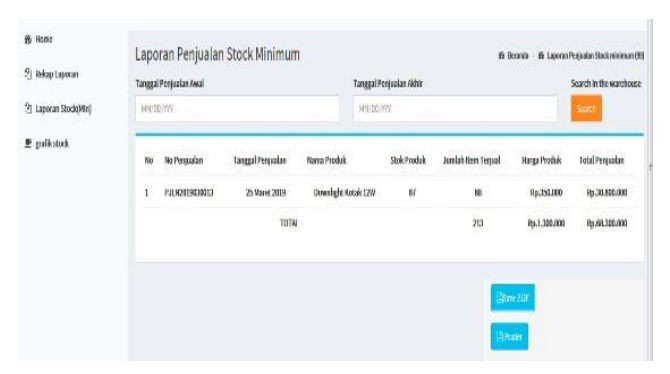

Gambar 14. Hasil laporan Minimal Stock Warehouse.

Pada Form laporan minimal stock Warehouse pada gambar 14, form ini hanya dapat dilihat oleh Owner dan manager. Bentuk laporan dapat di print dan disimpan dalam file pdff. Laporan ini ditampilkan berdasarkan periode tertentu.

\subsection{Tampilan grafik laporan penjualan}

Grafik di tampilkan berdasarkan sisa stok. Grafik pada system stock warehouse ini digunakan untuk mempermudah bagi seorang owner (pemilik) mempelajari hasil transaksi keluar masuknya barang dalam perusahaannya.

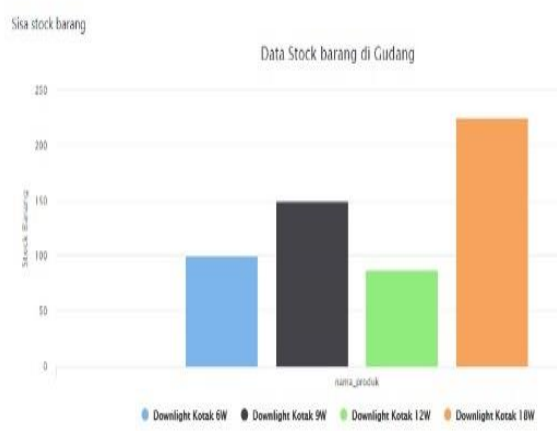

Gambar 15. Hasil grafik stok laporan penjualan.

Grafik stock pada gambar 15 menunjukan jumlah atau sisa stock barang yang bervariasi sesuai penjualan dan stok yang terdapat pada persediaan di gudang. laporan grafik ini mempermudah dalam pengambilan keputusan yang berkaitan dengan pengadaan barang atau penambahan stok ke dalam persediaan di gudang. Pada system ini juga sudah dilengkapi system monitoring stock minimal yang secara otomatis akan memberikan informasi tambahan pada saat laporan dibuat.

\section{KESIMPULAN}

Berdasarkan hasil penelitian yang mendapatkan identifikasi masalah serta melihat kondisi sistem yang sedang berjalan sampai pada pengembangan perancangan sistem aplikasi stok barang. maka dapat disimpulkan sebagi berikut:

1 Pengolahan data stok barang yang ada di PT. Mulia Andalan Gemilang sering tidak valid, dan tidak efisien dalam proses pencarian data dan pelaporan sehingga diperlukan perancangan sistem informasi yang baru. 
2 Menganalisa arus sistem informasi yang berjalan dan menghasilkan beberapa laporan stok barang.

3 Mendesain system sebagai alat bantu dalam proses keluar masuknya barang yang selalu bertambah dan berkurang dari stok di gudang.

4 Merancang dan membuat program aplikasi stok barang dengan menggunakan bahasa pemodelan $U M L$ dan serta implementasi menggunakan PHP7 yang berkolaborasi dengan system database MySqli.

5 Menganalisa peran serta Pengguna aplikasi ini dalam proses keluar dan masuknya stok barang.

6 Implementasi stok gudang pada sistem informasi ini dapat mengatasi masalah ke kosongan stok, hal ini di sebabkan stok sudah dapat di monitor dengan lebih cepat dan tepat dengan sistem yang di kembangkan ini. Stock gudang yang telah mencapai batas minimal akan tampil sebagai laporan stock yang harus di sediakan.

7 Dalam proses pengujian dengan metode Black Box test adalah 100\% layak dan hasil uji Alpha Test adalah 75\% sangat setuju, 25\% setuju. Maka dari hasil uji tersebut dapat disimpulkan bahwa aplikasi ini layak dan dapat digunakan dengan baik.

\section{SARAN}

Pengembangan sistem online ini dapat dikembangkan menjadi sistem yang lebih luas, yaitu melengkapi modul-modul tambahan seperti katalog produk dan keranjang belanja yang memungkinkan custommer dapat membeli barang secara langsung dan memilih produk yang dapat di proses melalui persedian barang di warehouse.

Bagi Supplier juga dapat mengajukan permohonan sebagai pemasok barang melalui mekanisme sistem online ini. Sehingga perpaduan bisnis khususnya penyediaan barang terus dapat bertransaksi dan berputar sesuai dengan banyaknya transaksi permintaan dari clien.
Semakin banyak kemudahan bagi pelanggan dan pemasok barang untuk ikut berperan serta dalam pemenuhan kebutuhan bisnis transaksi online mereka, maka perlu mempertimbangkan perkembangan sistem pasar atau marketing yang memudahkan dalam bertransaksi bagi pelaku bisnis, yaitu melalui jalur online.

\section{DAFTAR PUSTAKA}

[1] P. Cv, P. Indah, O. N. Cv, and P. Indah, "ANALISIS SISTEM MANAJEMEN PERGUDANGAN WAREHOUSING

MANAGEMENT

SYSTEM

ANALYSIS," vol. 6, no. 4, pp. 22782287, 2018.

[2] M. A.- Gyawu et al., "Assessing The Effects Of Information Technology ( ICT ) On The Performance Of Warehouse And Inventory Operations ( The Case Of Unilever Ghana Limited ) ISSN 2319-9725."

[3] P. Ndlala and C. Mbohwa, "The Application Inventory Control Systems in Warehouse," pp. 77-82, 2017.

[4] S. Sistem, I. Universitas, N. Pgri, K. Kediri, and I. E-mail, "Perancangan Active Database System pada Sistem Informasi Pelayanan Harga Pasar," vol. 1, no. 1, pp. 35-43, 2017.

[5] Y. Paul and Y. D. Lestari, "MANAGING STOCK IN WAREHOUSE : A CASE STUDY OF A RETAIL," vol. 4, no. 7, pp. 830-843, 2015.

[6] B. Systems, "A LITERATURE REVIEW ON MODELS OF INVENTORY Inventory management," vol. 5, no. 1, pp. 2635, 2015.

[7] R. Putra, "LAPORAN TUGAS SISTEM BASIS DATA ' Jurnal Sistem Basis Data ," 2017.

[8] N. H. Cahyana, B. Yuwono, and A. Y. Asmoro, "PENGEMBANGAN SISTEM INFORMASI PERSEDIAAN BARANG BERBASIS WEB DI PT . PUTERA 
AGUNG SETIA," vol. 2012, no. semnasIF, pp. 252-258, 2012.

[9] B. Arifudzaki, M. Somantri, and A. Fr, "Aplikasi Sistem Informasi Persediaan Barang pada Perusahaan Ekspor Hasil Laut Berbasis Web," vol. 12, no. 4, pp. 138-144, 2010.

[10] F. H. Staudt, G. Alpan, M. Di Mascolo, and M. Carlos, "Warehouse performance measurement: a literature review," Int. J. Prod. Res., vol. 7543, no. December 2017, pp. 1-21, 2015.

[11] R. S. V Aparajitha, "Perancangan Active Database System pada Sistem Informasi Pelayanan Harga Pasar," vol. 1, no. 8, pp. 73-76, 2010.

[12] H. S. Damesha, "Object Oriented Database Management SystemsConcepts,Advantages, Limitations and Comparative Study with RelationalDatabase Management Systems," vol. 15, no. 3, 2015.

[13] B. Kirankumar, S. D. Prasad, P. M. Manohar, K. Satyaprakash, M. Chiranjeevi, and K. V. Kiran, "DATABASE MANAGEMENT SYSTEM AND INFORMATION RETRIVAL," vol. 3, no. 2, pp. 36323637, 2012.

[14] A. Fitriya, "SISTEM INVENTORI BARANG DENGAN TEKNOLOGI AJAX," vol. 6, no. 2, pp. 367-374, 2015. 